\title{
Teachers' Concern about Implementation of Realistic Mathematics Education
}

\author{
Rahmah Johar, Cut Morina Zubainur, M. Ikhsan \\ Mathematics Education Department \\ Universitas Syiah Kuala \\ Aceh, Indonesia \\ rahmahjohar@fkip.unsyiah.ac.id
}

\begin{abstract}
Innovation is required in mathematics teaching in order to improve students' mathematics literacy. This means that students learn mathematics with the emphasis of common sense and application of knowledge in their daily life. Innovation can be conducted by employing the Mathematics Education (RME) approach. This is a developmental research which followed reference [1] model to measure the quality of learning using RME approach. The developed learning materials consisted of lesson plan, student's worksheet, observation sheet, achievement test, students' response, validation sheet, and video lessons. The quality criteria of the learning materials refer to validity, practicality, and effectiveness. This paper only discusses the effectiveness of innovation in terms of teachers' concern. The people who are impacted by the innovation may react differently. Ten primary school teachers were involved in the implementation of RME. They completed the questionnaire of teachers' concern after the implementation of RME in their own class. The results revealed that teacher are highly concern of the implementation of RME to develop students' character. Teachers are willing to review more of the approach including the change they should do related to the implementation of RME. Teachers are not concerned of the time constraint and more responsibility.
\end{abstract}

Keywords- Realistic Mathematics Education, Stages of Concern, Innovation

\section{INTRODUCTION}

Nowadays, education should focus on fostering innovation by emphasizing curiosity, critical thinking, and deep understanding as well as the rules and tools of inquiry, and creative brainstorming as the center of the curriculum. This is why Indonesian curriculum has been changed from Kurikulum Tingkat Satuan Pendidikan to Kurikulum 2013. Government have trained teachers and published textbooks. However, some mathematics materials in the primary school textbooks are presented with lack of demands for students to conduct the investigation using their common sense. Some of the mathematical activities also reach the abstract ideas too early. This is also found in junior high school textbook. Research by [2] have conducted analysis of several junior high school textbooks and conclude that the chapter are mostly started with explanation by demonstrating mathematics procedure to solve problems with lack of support for students to discover their own strategies. In addition, the Indonesian textbooks usually provide word problems after the explanation of mathematical procedures without providing context to build students' modeling in solving problems. They concluded that Indonesian' students mainly have difficulty in comprehending a context-based problems and in transforming them into a mathematical problem.

Indonesian students tend to use standard strategies provided in the textbook or being taught by their teachers and therefore their answers are lack of variation when they are asked to solve the problem using their own way [3]. Furthermore, when students are asked to explain why they use the strategy, most of them admit that they do not know. The teacher did that. I think I should follow her, and it works. I got the answer" [4]. Therefore, innovation is required in mathematics for students to have meaningful mathematics learning by taking into account of the children and current development. One of the innovations is the implementation of Realistic Mathematics Education (RME) approach

The RME idea was inspired by Freudenthal who argued that mathematics as a human activity, where students are guided by teacher through a meaningful and useful activity so that they learn as if they discover mathematics by themselves [5]. Students start the lesson by solving a rich context to develop their understanding and their own strategies [6][7] while teacher help to improve students' strategies to a more advance level or more [8]. Therefore, the role of students and teachers should be changed to implement RME in Indonesia. Teachers need to design challenging contextual problems, students should be confident in expressing their opinion in solving the problems without being scared of making mistakes and teachers should not be in hurry in providing the students direct answers [9] [10].

In Indonesia, RME is known as Pendidikan Matematika Realistik Indonesia (PMRI) and has been handled by 17 Teacher Training Institutions (LPTK) since 2001. Each LPTK has a study center called P4MRI, such as the P4MRI of Syiah Kuala University (UNSYIAH) which program including conducting workshop for teacher, coaching teachers in teaching mathematics, conducting research and organizing conferences [10] [11].

From 2014 to 2016, authors have been intensively developed learning materials including lesson plans, students' worksheets, and video lessons of model teachers in 
implementing RME. Teachers from the pilot school of P4MRI Unsyiah are invited to join workshop to discuss learning materials and watch video lessons of RME implementation to be applied in their own classrooms [12]. According to [13], the role of lecturers as the member of P4MRI Unsyiah is considered as a trainer of consultant as well as the agent of change in any process of educational innovations. On the other hand, teachers are the one who are influenced by the learning innovation using RME. Furthermore, teachers are also the agent of change in facilitating students to be independent learners that play important role in the learning innovation. This indicates that everyone is an agent of change [14].

The change due to an innovation is not an instant process and should not be forced, it is rather a journey requires mentoring and peer coaching [14]. Change is a dynamic and non-linier process that cannot be predicted or assisted the process accurately [15]. Therefore, great collaboration between lecturers and teachers in planning, conducting and evaluating the innovation is required.

The people who are impacted by the innovation may react differently [16][17]. The innovation may be in line with the beliefs for some people but contradicts with some others' personal goal and educational view [18].

The teacher's level of acceptance of the innovation is influenced by the conformity with their daily task at schools [14], relative advantage, complexity, compability, observability (Rogers in [19]), teachers' experience, attitude, and perception [19]. Studies found that individual concerns in the process of adopting educational innovation is a developmental in nature that begin with focusing on self (such as do I understand this innovation), task (such as how will I do this innovation) and the impact (how the innovation will influence my students) [20].

In [21] investigated how educational fails to reach extensive adoption. Among the factors contributing the failure is that there was lack of attention to the concerns individual adopters and the importance of this concern in relation to the organizational structure and support were not properly acknowledged. They discovered that the major factor is the sophistication of the educational education combined with the individual differences in each organization, classroom and teaching style. In [21] also developed the change process known as the Concerns-Based Adoption Model (CBAM) based on Fullers' original research at 1969. The model comprises of three stages including Stages of Concern, Levels of Use, and Innovation Configuration. Stages of Concern are more commonly used than the other stages [16].

Stages of concerns focuses on the expressed adopter concerns and problems related to his or her experience of the innovation. User feelings, feelings, observations, problems, successes, and failures in the process of innovation adoption are analyzed. The results of the analysis can inform the change facilitators and innovation sponsors the readiness of the adopters to accept the innovation. There are seven levels of stages of conecrn, including awareness, informational, personal, management, consequence, collaboration, and refocusing [21]. One of the benefits of the investigation of stages of concerns of the adopter is that additional preparation and support can be given to the teacher who is highly concerned about how to use the innovation in the classroom [16].

This paper focus on studying the Stages of Concern of teachers in implementing RME for teaching mathematics at primary schools after the intervention of P4MRI Unsyiah team. The research question is "what is indicated in each level of teachers concerns in implementing RME for teaching mathematics at their classess?

\section{METHODS}

This study is a part of developmental research which followed [1] model. The developed learning materials consisted of lesson plan, student worksheet, observation sheet, achievement test, students' response, validation sheet, and video lessons. The quality criteria of the learning materials refer to validity, practicality, and affectivity. This paper is only discussed the affectivity of innovation in terms of teachers' concern. Ten primary school teachers in Banda Aceh, Indonesia, from a partner schools were involved in the implementation. Only 2 out of 10 teachers have joined RME workshop of RME handled by P4MRI of Syiah Kuala University, 2 other known about RME from their lecturer at Syiah Kuala University, 2 others just know about the name of RME, others never heard about RME

Before the implementation of RME for teaching decimal number for grade 4 of primary school students, P4MRI Unsyiah conducted two days workshop about the characteristics of RME, modelling for teaching decimal, discussing about teaching materials, as well as showing video for teaching decimal number. Then, all of teachers implemented them in their own classes for the first lesson. Researchers observed and recorded their lessons and provide feedbacks. The teachers were then invited again to the workshop to share their experience and discuss the challenge they faced with their peers. Furthermore, the preparation for the second lesson of decimal number was also discussed. They were also invited again to the workshop after the second lesson to compare the issues they have encountered during the implementation. At the end of the workshop (on 8 September 2016), the questionnaire of Stage of Concern (SoC) adopted from [22] is administered to the teachers.

The questionnaire of teachers' concern consists of 35 items. The items are divided into seven categories including awareness, informational, personal, management, consequence, collaboration and refocusing [22]. Each category consists of five statements. The responses are "strongly agree,", "agree", "disagree" and "strongly disagree". The descriptive analysis is carried out to investigate the percentage of teachers' responses related to their concerns of the implementation of RME.

\section{RESULTS AND DISCUSSION}

Table 1 shows teachers' responses on the statements provided. 
TABLE I. TEACHER'S CONCERN DATA OF THE IMPLEMENTATION OF RME

\begin{tabular}{|c|c|c|c|c|c|c|c|c|c|c|c|c|c|c|c|c|c|c|c|c|c|c|c|c|c|c|c|c|c|c|c|c|c|c|c|}
\hline \multirow[t]{2}{*}{ Kategori } & \multicolumn{5}{|c|}{ Awareness } & \multicolumn{5}{|c|}{ Information } & \multicolumn{5}{|c|}{ Personal } & \multicolumn{5}{|c|}{ Management } & \multicolumn{5}{|c|}{ Consequence } & \multicolumn{5}{|c|}{ Collaboration } & \multicolumn{5}{|c|}{ Refocusing } \\
\hline & 3 & 12 & 21 & 23 & 30 & 6 & 14 & 15 & 26 & 35 & 7 & 13 & 17 & 28 & 33 & 4 & 8 & 16 & 25 & 34 & 1 & 11 & 19 & 24 & 32 & 5 & 10 & 18 & 27 & 29 & 2 & 9 & 20 & 22 & 31 \\
\hline STS & 5 & 5 & 4 & 0 & 3 & 1 & 0 & 0 & 0 & 0 & 0 & 0 & 0 & 0 & 0 & 1 & 2 & 1 & 0 & 1 & 0 & 0 & 1 & 0 & 0 & 0 & 1 & 1 & 0 & 0 & 0 & 0 & 0 & 1 & 0 \\
\hline TS & 3 & 4 & 6 & 0 & 7 & 5 & 0 & 0 & 0 & 0 & 0 & 0 & 0 & 0 & 1 & 7 & 5 & 6 & 1 & 6 & 1 & 0 & 0 & 0 & 1 & 1 & 1 & 1 & 1 & 0 & 0 & 0 & 1 & 1 & 1 \\
\hline$S$ & 2 & 1 & 0 & 5 & 0 & 4 & 9 & 6 & 7 & 5 & 8 & 5 & 7 & 5 & 6 & 2 & 3 & 3 & 6 & 3 & 4 & 7 & 7 & 7 & 5 & 9 & 4 & 8 & 5 & 10 & 9 & 10 & 8 & 4 & 7 \\
\hline SS & 0 & 0 & 0 & 5 & 0 & 0 & 1 & 4 & 3 & 5 & 2 & 5 & 3 & 5 & 3 & 0 & 0 & 0 & 3 & 0 & 5 & 3 & 2 & 3 & 4 & 0 & 4 & 0 & 4 & 0 & 1 & 0 & 1 & 4 & 2 \\
\hline
\end{tabular}

Based on teacher's responses on the category of awareness, it is shown that most teachers disagree or strongly disagree with the statement of 'I do not have any idea of this innovation' ( $80 \%$ ) and 'I am not interested in this innovation' (90\%). Furthermore, all teachers disagree or strongly disagree with the statement of 'Even though I do not have any idea of this innovation, I am interested in the things related to this innovation'. In addition, all teachers also strongly disagree or disagree with the statement of "Currently I am not interested in learning this innovation"

For the category of informational, most teachers $(60 \%)$ strongly disagree or disagree with the statement of ' $I$ have a limited knowledge about this innovation'. Furthermore, all teachers agree or strongly agree with the statement of 'I want to review the possibility of implementing this innovation, I want to know the resources used to implement this innovation, I want to know the preparation needed to implement this innovation in the near future, and I want to know the advantages of this innovation compared to the teaching strategy I have used so far'.

For the category of Personal, most teachers (60\%) strongly agree or agree with the statement of 'I want to know the impact of this innovation on the my professional improvement, I wonder whether this innovation is in line with the current curriculum, I want to know what change needed in term of the teaching strategy and preparation to implement this innovation, I want more information related to time and effort required to implement this innovation'. Furthermore, most teachers $(60 \%)$ agree or strongly agree with the statement of 'I want to know how my roles change when I implement this innovation'.

For the management category, the majority of teachers disagrees or strongly disagrees with the statements of 'I am concerned that I do not have enough time to prepare the lesson each day if I implement this innovation (80\%), I am interested in this innovation but I am concerned that it will increase my responsibility (70\%), I am concerned of my inability to prepare everything needed in this innovation (70\%)'. Preparing the task and coordinating with people take too much of my time $(70 \%)$. On the other hand, most teachers $(90 \%)$ agree or strongly agree with the statement of 'I am concerned of the time spent for non academic activities related to this innovation'

For the category of consequence, the majority of teachers agrees or strongly agrees with the statements of 'I am concerned of the impacts of this innovation on students' behavior, I am concerned of how my teaching ability impacting on the students, and I want to use feedbacks from students to improve this innovation. While for the statement of 'I am concerned of the impacts of this innovation on students' achievement and I want to motivate students for their roles in this innovation', all teachers agree or strongly agree.

For the category of collaboration, the majority of teachers agrees or strongly agrees with the statements of 'I want to help other teachers in implementing this innovation (90\%), I want to develop cooperative relationship with teachers in my school or other schools about this innovation' $(80 \%)$, I want to socialize this innovation to the other teachers of party $(80 \%)$, I will work together with the other party to maximize the impacts of this innovation $(90 \%)$. Furthermore, all teachers agree or strongly agree of the statement of 'I want to know what other teachers do in relation to this innovation'.

For the category of refocusing, all teachers agree with the statement of 'Now I know better strategies to use with this innovation and I care to revise my implementation of this innovation'. In addition, most teachers agree or strongly agree with the statements of 'I want to revise the learning approach used in this innovation (90\%), I want to modify the implementation of this innovation based on students' experience $(80 \%)$, and I want to determine how to perfect, improve and revise the innovation (90\%).

The responses of the teachers of the awareness category show that all teachers state that they are familiar with RME approach, even though some teachers joined the RME workshop for the first time because of their recent employment in the partner school. This indicates that teachers obtain information related to RME not only from the workshop for RME teacher but also from other resources. This in line with[23] who found that teachers obtain information about RME not only from the workshop for RME teacher but also from other resources such as educational seminars and reading resources and material obtained in the course. Furthermore, most teachers say that they are interested in RME approach. This is in line with [24] who discovered that teachers are interested in implementing RME approach.

Similar trends occur for the category of informational and personal. All teachers state that they are willing to review more of RME. This is related to the resources used, the preparation needed for the implementation of RME and the impact of the implementation of RME on their professional improvement and the conformity of RME to the current curriculum. All teachers also want to know the change 
required related to the implementation of RME in term of teaching strategy and preparation, time, efforts and role. This is in line with [25], [26], and [27] who argued that the implementation of RME requires teachers' understanding on students' involvement, the importance of discussion to get information related to $\mathrm{RME}$ and the situation required to implement and sustain the implementation of RME. Teachers are required to follow the RME principles while adapting with the students. The implementation of RME should provide teachers opportunities to be an active participant instead of a passive receiver. This is in line with [28] who emphasized that teacher should know and understand the change to do. Teachers also require understanding that some of the current activities may be useless with the implementation of RME. According to [29] and [30], the implementation of RME will be rejected if there is a big change which is not considered as an improvement.

For the category of management, most teachers state that they are not concerned of not having enough time to prepare the lesson each day if they implement RME approach. Most teachers are also interested and not concerned that it will add more responsibility. Furthermore, they are not concerned about not being able to prepare everything needed for the innovation. Most teachers are not concerned about spending too much time to prepare the task and working with other people. There are only a small number of teachers who state that they are not concerned about spending much time for non academic activities related to the implementation of RME. These are an significant finding as [31] argued that the change such as the implementation of RME are often seen by teachers as the addition of workload on top of the high workload they have already had. The benefits of the implementation of RME should be received by teachers to avoid their rejection.

For the category of consequence, nearly all teachers agree respond that they care of the impacts of the implementation of RME on students' behavior and achievement as well as their teaching ability. All teachers are willing to motivate students of their role in the lesson with RME approach. Nearly all teachers are willing to use feedbacks from students to improve the implementation of RME. This is relevant to [32] and [33], and [28] who explained that students should be involved in implementing a change based on their maturity and the sophistication of the change done. This is supported by [34] who found that the success of a change is determined by the interaction between teachers and students. Therefore, teachers should work as a team with the students. Furthermore, [31] argued that it is crucial for teachers to know the impacts of the change on the students. According to [35] and [36] among the challenges are students with different background, ability, interest and talent. Therefore, teachers need to be certain that the RME learning can accommodate all students.

\section{CONCLUSION}

Based on the responses of teachers on the questionnaire related to the implementation of RME, it can be concluded that the teachers are having a great concern about the implementation of RME. Teachers are willing to learn more about RME and its impacts for both their professionalism and students. Teachers are also willing to know the change required related to the implementation of RME. Furthermore, teachers are not concerned about not having enough time or adding more responsibility.

\section{ACKNOWLEDGMENT}

Many has been involved in this research. I would like to express my gratitude for their motivation, guidance and coaching. Especially, I would like thank the Research, Technology and Education Ministry for the grant competition for 2014-2016 Nomber: 025/SP2HL/LT/DRPM/II/2016.

\section{REFERENCES}

[1] T. Plomp, An introduction to educational design research. In T. Plomp, $\&$ N. Nieveen, (Eds), Proceedings of the seminar conducted at the East China Normal University, China: Shanghai, 9-36, 2007.

[2] A. Wijaya, M. van den Heuvel-Panhuizen, \& M. Doorman Opportunity-to-learn context-based tasks provided by mathematics textbooks, Educational Studies in Mathematics, 89, 41-65, 2015.

[3] R. Johar, S. M. Patahuddin, \& W. Widjaja, Linking pre-service teachers' questioning and students' strategies in solving contextual problems, A case study in Indonesia and the Netherlands, The Mathematics Enthusiast, 14(1), 101-128, 2017.

[4] D. Armanto. Teaching multiplication and division realistically in Indonesian primary Schools: A prototype of local instructional theory, Enschede: Print Partners Ips kamp, 2002.

[5] H. Freudenthal, Didactical Phenomenology of Mathematical Structures, Dordrecht: D. Reidel Publishing Company, 1983.

[6] M. van den Heuvel-Panhuizen, Assessment and Realistic Mathematics Education. Utrecht, (The Netherlands: CD- $\beta$ Press/Freudenthal Institute, Utrecht University, 1996.

[7] M. van den Heuvel-Panhuizen and M. Wijers, Mathematics standarsa and curricula in the Netherlands, ZDM Mathematics Education, 37(4), 287-307, 2005

[8] K.P.E. Gravemeijer, Developing Realistic Mathematics Education. Netherland: Technipress, 1994

[9] M. Dolk, Improving mathematics and science education: a Dutch example, In Procceding of the Sriwijaya University Learning and Education-International Conference, A4 24-29, 2014.

[10] R. K. Sembiring, S. Hadi \& M. Dolk, Reforming mathematics learning in Indonesian classrooms through RME. ZDM Mathematics Education, 40, 927-939, 2008.

[11] R. Johar. PMRI in Aceh. In Sembiring, R. K. Hoogland, K. \& M. Dolk, (Eds), A decade of PMRI in Indonesia, Utrecht: APS International, 175187, 2010.

[12] R. Johar, C. M. Zubainur, dan M. Ikhsan. Tingkat Kepedulian (Stages of Concern) Guru Memanfaatkan Video dalam Melaksanakan Pembelajaran Matematika dengan Pendekatan Realistik untuk Mengembangkan Karakter Siswa. Research report. Universitas Syiah Kuala (Unpublished), 2016.

[13] G. Badley. The teacher as change agent. British Journal of in-Service Education, 12(3) 151-158, 1996.

[14] M. Fullan, Change Forces: Probing the D of Educational Reform, School Development and Management of Change Series: 10, London: the Falmer Press, 1993.

[15] R. Stacey, Managing the Unknowable, San Fransisco, CA: Jossey-Bass, 1992.

[16] K. Halloway, A Research-based Program Aids Innovation by Addressing Teacher Concerns. National Staff Development Council. www. Nsdc.org, 2003.

[17] S. A. William, Stages of Concern of Teachers in North Carolina 4/4 Block Scheduled Public Schools, Virginia: Virginia Polytechnic Institute and State University, 2010

[18] E. Ketelaar, E. Teachers and innovations: on the role of ownership, sense-making, and agency Eindhoven, Technische Universiteit Eindhoven DOI: 10.6100/IR732586, 2012.

[19] P. A. Alfieri, Stages of Concern of Defense Systems Management College Faculty about Technology-Based Education and Training. 
Disertasi Faculty of Virginia Polytechnic Institute and State University, 1998.

[20] F. Fuller, Concerns of teachers: A developmental conceptualization. American Educational Research Journal, 6(2), 207-226, 1969.

[21] G.E. Hall, R.C. Wallace, \& W.A. Dossett, A developmental conceptualization of the adoption process within educational institutions. Report No. 3006. The University of Texas at Austin: Research and Development Center for Teacher Education. ERIC Documentation Reproduction Service No. ED 095126), 1973.

[22] G. E. Hall and S. M. Hord. Implementing Change Patterns, Principles, and Ppotholes, Boston, MA: Allyn and Bacon, 2001.

[23] C.M. Zubainur, Pengajaran dan Pembelajaran Pendidikan Matematik Realistik Indonesia di Sekolah Rendah Aceh, Unpublished dissertation, Universiti Utara Malaysia, 2015.

[24] S. Hadi, Pendekatan Matematika Realistik: Teori, Pengembangan, dan Implementasinya, Jakarta: Rajawali Pers, 2016.

[25] J. R. Wiens, Educational Leadership as Civic Humans. Dalam Paul Kelleher and Rebecca van der Bogert, Voices for Democracy: Struggles and Celebrations of Transformational Leaders, 199-225 (105 ${ }^{\text {th }}$ ed.). Yearbook, Part I, Malden, MA: National Society for The Study of Education/Blackwell, 2006

[26] E. Campbell, Curricular and professional authority in schools, Curriculum Inquiry, 36(2), 111-118, 2006.
[27] C. Drake, \& M. G. Sherin, Practicing Change: Curriculum Adaption and Teacher Narrative in the Context of Mathematics Education Reform, Curriculum Inquiry, 36(2), 153-187, 2006.

[28] A. C. Ornstein, F. P. Hunkins, Curriculum: Foundation, Principles, and Issues. New Jersey: Pearson Education, Inc, 2013.

[29] K. Egan, The Future of Education. New Haven: Yale University Press, 2008.

[30] S. Ali, Class Action. Newsweek, 4, 2010, November 8.

[31] T. R. Harvey, Checklist for Change, Boston: Allyn \& Bacon, 1990.

[32] D. Thiessen, Student Knowledge, Engagement, and Voice in Educational Reform, Curriculum Inquiry, 36(4) 345-358, 2006.

[33] A. Cook-Sather, Sound, Presence, and Power: Student Voice in Educational Research and Reform, Curriculum Inquiry, 36(4), 359-390, 2006.

[34] K. Hoogland, Critical success factors for an effective implementation. A case study: PMRI. Presented at Conference on the Recent Progress in Mathematics Education (CRPME), Bandung, September, 2004.

[35] R. Soder, The Lenguage of Leadership, San Francisco: Jossey-Bass, 2001.

[36] K. T. Henson, Curriculum Planning: Integrating Multiculturalism, Constructivisme, and Educational Reform (2 ${ }^{\text {nd }}$ ed.), New York: McGraw-Hill, 2001. 